\title{
Earthkeepers in the Czech Republic: Experience from the implementation process of an earth education programme
}

Jan Činčera, Bruce Johnson

Envigogika 8 (4) - Reviewed Papers

Publikováno/Published 31. 12. 2013

DOI: http://dx.doi.org/10.14712/18023061.397

\begin{abstract}
:
The article presents experience with implementation of the international Earthkeepers earth education programme in the Czech Republic. The paper begins with an evaluation of the implementation process from the point of view of the staff of the Bohemian Paradise Ecological Education Centre (Středisko ekologické výchovy Český ráj) that prepared and conducted the Czech version of the programme. According to their assessment, the process was challenging, demanding, and rewarding. In the second part, the article analyzes pupils' (age 10-12) and teachers' satisfaction with the programme. The respondents expressed a high level of satisfaction, with the programme having a lingering effect on following school lessons. The last part presents the effects of the piloted programme on pupils' ecological knowledge and attitudes. The results proved to have a positive impact of the programme on both variables. Implications for further dissemination of the programme in the Czech Republic are discussed.
\end{abstract}

\section{Keywords:}

Earth education, evaluation, attitude, ecological knowledge

Strážci země v České republice: zkušenost s implementací programu výchovy o zemi

\section{Abstrakt:}

Článek prezentuje zkušenosti $s$ implementací mezinárodního programu výchovy o Zemi Strážci Země v České republice. $\vee$ první části hodnotí proces implementace z pohledu zaměstnanců Střediska ekologické výchovy Český ráj, které připravilo a vedlo českou verzi programu. Podle nich byla implementace náročnou, ale obohacující výzvou. Ve druhé části článek analyzuje spokojenost žáků (10-12 let) a učitelů s programem. Respondenti vyjadřovali vysokou míru spokojenosti s programem, který ovlivnil i navazující školní lekce. $\checkmark$ poslední části prezentuje efekt pilotního programu na ekologické znalosti a postoje žáků. Výsledky dokládají pozitivní vliv programu na obě proměnné. $V$ závěru pak jsou diskutovány možnosti dalšího šíření programu v České republice.

\section{Klíčová slova:}

Výchova o Zemi; evaluace; postoje; ekologické znalosti 


\section{Introduction}

Earthkeepers (Van Matre \& Johnson, 1988) is an earth education programme developed and disseminated by The Institute for Earth Education (IEE), an international notfor-profit educational organization. Earth education is the process of helping people live more harmoniously and joyously with the natural world (Van Matre, 1990). Designed for 10-12 year olds, Earthkeepers is a "magical learning adventure" that helps young participants develop a deeper understanding of the ecological systems on our planet, cultivate feelings of connection to the natural world, and take actions to reduce their impact on ecosystems. Like all earth education programmes, Earthkeepers is based on a programmatic approach rather than the more common infusion approach found in much of environmental education (Wohlers \& Johnson, 2003). The program is holistic, with every activity selected purposefully to help accomplish specific goals.

Earthkeepers is organized with the word KEYS, which summarizes the major components of the programme. The learning begins with a three-day 'springboard' experience that takes place at the Earthkeepers Training Centre, a natural area away from school. The focus is on Knowledge $(K)$, building up an understanding of the ecological concepts of energy flow, materials cycling, interrelationships and change, and Experience (E), developing personal feelings for nature. Then the program continues back at school and at home, applying the Knowledge and Experience to Yourself (Y), making personal choices to use less energy and materials and to have new experiences in nature, and Sharing (S) all of this with others. Participants in Earthkeepers earn four keys (K, E, Y, S) as they complete the different parts of the programme. Each key opens a box that contains secret meanings according to E.M., a mysterious character who has set up the experience for the learners. The secret meanings capture the essence of each part of the programme, helping the learners to retain what they have learned while also providing a great deal of excitement and anticipation.

After initial development in the United States, Earthkeepers has spread widely. The programme has been translated from English into Chinese, Dutch, Finnish, Greek, German, Italian, Japanese, and Spanish, as well as Czech. It has been implemented in 14 different countries. In most cases, an outdoor school nature centre offers the programme, and school classes visit the centre for a three-day springboard experience, often staying overnight, but sometimes just going three days in a row.

There have been several evaluation studies of the Earthkeepers programme. Increases in student understanding of ecological concepts, more pro-environmental attitudes and values, and the adoption of more ecologically-friendly behaviours have been consistently shown (Johnson \& Manoli, 2011; Manoli \& Johnson, 2007). In addition, a new study (Felix \& Johnson, 2013) investigated the continuation of the programme back in the classroom after the initial three-days' experience. The most recent study of Earthkeepers (Manoli, et. al, 2013) took place in Cyprus, showing gains in ecological understandings, attitudes and values, and behaviours, along with high rates of satisfaction from participants and their teachers.

Although earth education was not completely unknown in the Czech Republic (Ledvinova et al., 1992, Hakr \& Cincera, 2006, Cincera, 2007a), no earth education programme had been conducted there before 2012. The breakthrough was a workshop held by Steve van Matre for staff of Czech environmental education centres in Sedmihorky in 2007 (Cincera, 2007b). After the workshop, the Bohemian Paradise Ecological Education Centre decided to join the earth education movement and launch one of their programmes. 
Among the published earth education programmes, Earthkeepers was selected as the programme that was relatively less demanding in terms of implementation in comparison with other earth education programmes. After obtaining financial support from European funds in 2011, the implementation process started.

In 2012-2013, six classes participated in piloting the programme. Thanks to financial support, participation was free of charge.

This article discusses the experience of the staff of the Bohemian Paradise Ecological Education Centre with implementation of the programme and presents data obtained in the evaluation process.

\section{Methodology}

The article focuses on the following questions:

- How did the members of the Czech environmental education centre reflect on their experience with implementation of the programme?

- What was the satisfaction of teachers and pupils with the programme?

- What effects did the programme have on ecological knowledge and attitudes of pupils?

To answer these questions, the evaluation used a mix of qualitative and quantitative instruments. During the implementation process, the Czech evaluator visited the programme three times and observed the way it was conducted. To record the perspective of the staff of the centre, non-structured interviews were repeatedly undertaken $(\mathrm{N}=4)$.

The teachers' perspective was analyzed with the help of questionnaires $(\mathrm{N}=7)$ and following online interviews $(\mathrm{N}=3)$. The level of pupils' satisfaction was measured with a postquestionnaire Program Satisfaction Survey (PSS) $(N=120)$ conducted after finishing the residential part of the programme. After finishing the school part, pupils received a final Program Follow-Through Survey (PFTS) questionnaire for reporting how they had completed the programme $(\mathrm{N}=107)$. The questionnaires were distributed by teachers who received instruction for their administration.

Pupils' attitudes and values were measured with the Environmental Scale (2-MEV), a 16-item Likert scale-based instrument modified by Johnson and Manoli (2008) and based on Bogner and Wiseman (2006) (see Apendix 1). Czech translation of the instruments had been repeatedly verified and validated by a panel of experts and by its implementation on different sets of pupils. The internal reliability of the instrument was measured on Cronbach alpha $=0.83$.

The pupils' ecological knowledge was tested by a 13-item ECQ instrument, created by Johnson and Manoli (2008). The test provides pupils with a set of multiple-choice questions assessing the level of their understanding of energy flow (6 items), cycles of materials (3 items), change ( 2 items), and interdependence ( 2 items). In each of the items, pupils could gain 0 (wrong) or 1 (correct) points.

The 2-MEV and ECQ were administrated 1-2 weeks before and 2-4 weeks after the programme. Pupils' and teachers' satisfaction was measured 2-4 weeks after the programme. 
Pre- and post-tests were matched and analyzed by the paired t-test and paired Wilcoxon test (alpha=0.05). While the data in 2-MEV pre-test tended to be skewed left (especially considering the Preservation factors), the Kolmogorov-Smirnov test for the whole test still correspondented to normal distribution $(d=0.07, p>0.2)$. Based on this data analysis, the t-test was considered as appropriate. Data from 106 pupils - 54 girls and 52 boys - were used for analysis. The mean age was 11.5 years $(S D=0.7)$.

For comparison, a control group consisting of two classes from the same region that did not participate in the programme was asked to fill in pre- and post-tests in the same time-span (6-8 weeks) as the experimental groups. During this time, the control group did not participate in any special environmental education programme, although they held their regular biology lessons. The control group consisted of 37 pupils of an average age of 11.0 years $(S D=0.5)$.

\section{Results}

\subsection{Implementation of the programme}

According to the staff, the implementation process was challenging, demanding, and rewarding. At the beginning, the staff had only a rough idea of the way the programme worked. Despite their effort to see the programme being run in other countries, they were not successful. Because of this, they had to work with indirect experience obtained from books, external consultants, and the author of the programme who visited Sedmihorky and conducted a workshop for the staff. According to the respondents, this workshop was crucial for grasping the way the program should be conducted.

The translation process appeared to be much more difficult than the staff members had anticipated. The programme had a specialized vocabulary with subtle meanings. It was necessary to find Czech equivalents with the same connotation for pupils from a different socio-cultural environment. For example, one of the activities used in the programme is called 'The Great Speck-tackle'. The name presupposes that participants will see something extraordinary. However, there is also a meaning in the word 'speck' which is used as a central concept for the activity explaining the concept of material cycles. As an equivalent for the term 'speck', a newly-invented Czech word 'zemekousek' (Earthspeck) was used, keeping both levels of meanings.

Even if the centre had hired a translation company, the translation process would not work without an understanding of the earth education context. Moreover, the translated text had to be verified by the IEE, which made it slow and complicated. The staff reflected that the verification process was extremely demanding in terms of both time and energy.

In spite of these obstacles, the staff highly appreciated the benefits of the programme for their centre. They mentioned that the programme corresponded with the way they wanted to go at the centre and that they agreed with the programme emphasis on direct experience and magical adventure. Launching the programme in 2012 also helped with public relations at the centre and its position in the environmental education community. The staff presented the programme at the regular 'Fair of environmental education programmes' held by the Czech centres in 2012, and attracted a lot of attention for both the programme and the centre. Now, the centre plans to conduct 8-10 runs of the programme for the 2013/14 school year. 


\subsection{Satisfaction with the programme}

According to the results, pupils were highly satisfied with the programme. When asked if they liked the Earthkeepers programme, 97\% responded that they had liked the programme quite well or a lot, with only $2 \%$ indicating they had not liked it. Fewer than five percent of the respondents declared some level of dissatisfaction with the programme (see Image 1).

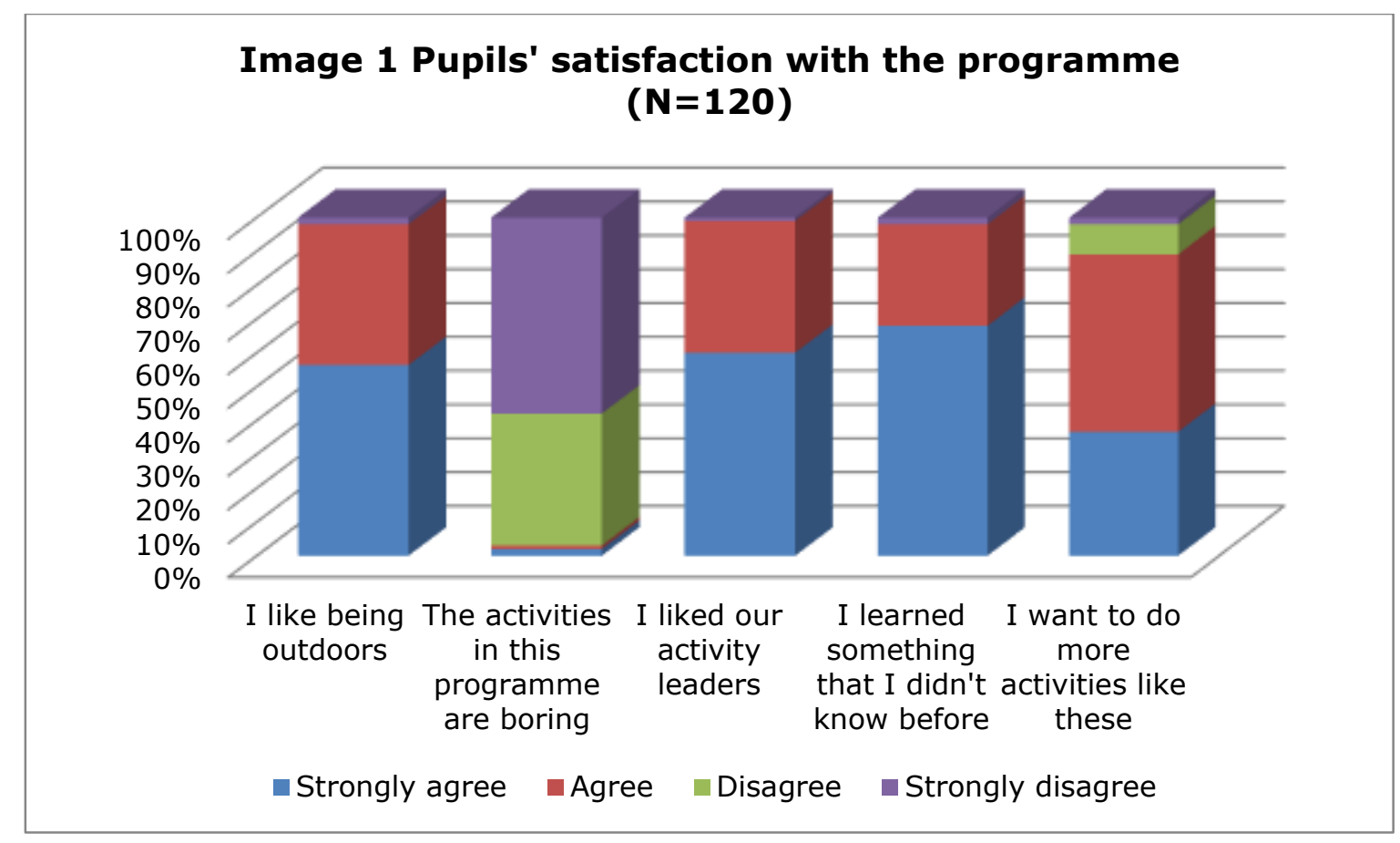

Of the 120 respondents, 93\% declared their willingness to participate in the programme again. No significant difference was found by the Fisher exact test between girls and boys $\left(\mathrm{x}^{2}=0.18, \mathrm{p}=0.25\right)$.

Pupils gave very positive reasons why they would like to do the programme again. Usually, they reported they had liked the programme and its activities, had learned new things, and they often used superlatives. According to one of the respondents

'It was a great adventure and I will never forget it.'

For the pupils, the programme was fun. They appreciated the work of the trainers (staff) and reported they gained new knowledge and attitudes, and learned new behavior. Pupils also liked the symbolic framework of the programme, even if some of them expressed regret they did not meet E.M. face-to-face.

There were few negative reactions. One of the respondents missed his computer. Another recommended playing 'more normal games', as it is common at summer camps. Three respondents mentioned cold weather.

The feedback from the teachers was also highly positive. Respondents appreciated the careful preparation of the programme, the enthusiasm of the trainers, and the surprisingly high level of involvement of the pupils. 
The teachers were able to join the programme with follow-up school lessons. According to one of the respondents, pupils reflected at school on how they came to understand in the programme that all things in the environment are interconnected; they also recalled the concepts of cycles and changes.

According to another respondent, pupils referred to the programme 1-2 times per week in the following months. They also started to switch off lights more carefully than before. She appreciated the way the activities are interlinked. She was also deeply impressed by the Earth Walks, especially by the activity Eye on the Sky.

\subsection{Effect of the programme}

The impact of the programme on pupils' attitudes and values was analyzed with the 2-MEV instrument using a Likert-type scale, with mean scores ranging from 1 to 5 . The 2MEV measures two values: Preservation, a measure of the degree to which people value the preservation of nature, and Utilisation, a measure of the degree to which people view nature as a resource to be utilized by humans. Preservation consists of three primary attitudes: Intent of Support (of environmental causes), Care with Resources, and Enjoyment of Nature; for these, mean scores above 3 are indicative of pro-environmental values and attitudes. Utilization consists of two primary attitudes: Altering Nature and Human Dominance; for these the opposite is true, so mean scores below 3 are indicative of pro-environmental values and attitudes.

For those who participated in the Earthkeepers programme, the value of Preservation and two of its primary attitudes, Intent of Support and Care with Resources, became more pro-environmental after the programme. For the attitude of Enjoyment of Nature and for the value of Utilisation and the attitudes of Altering Nature and Human Dominance, mean scores became more pro-environmental, but the changes were not large enough to be statistically significant (see Table 1).

Table 1. Environmental attitudes and values of participating students before and after the programme $(\mathrm{N}=106)$

\begin{tabular}{lllllllll}
\hline & \multicolumn{9}{c}{ Mean Scores } & \multicolumn{2}{c}{ Std. Deviation } & & & \multirow{2}{*}{ Effect size } \\
\cline { 2 - 6 } & Pre & Post & Pre & Post & $\boldsymbol{T}$ & $\boldsymbol{p}$ & \\
\hline Preservation & 4.06 & 4.28 & 0.73 & 0.78 & -2.21 & $0.029 *$ & 0.29 \\
Intent of Support & 3.60 & 3.90 & 1.00 & 0.96 & -2.63 & $0.010 *$ & 0.31 \\
Care with Resources & 4.14 & 4.47 & 0.93 & 0.86 & -3.01 & $0.003 *$ & 0.37 \\
Enjoyment of Nature & 4.40 & 4.45 & 0.78 & 0.86 & -0.48 & 0.631 & 0.06 \\
Utilization & 2.41 & 2.26 & 0.77 & 0.86 & 1.69 & 0.094 & 0.18 \\
Altering Nature & 2.81 & 2.60 & 0.92 & 0.98 & 1.93 & 0.056 & 0.22 \\
Human Dominance & 1.87 & 1.81 & 0.81 & 0.88 & 0.58 & 0.565 & 0.07
\end{tabular}

Note: *statistically significant, $p<0.05$ 
For the control group students who did not participate in Earthkeepers, the only statistically significant change was for the attitude of Care with Resources, which became more pre-environmental (see Table 2). Because the control group did not participate in any type of environmental intervention between completing the pre- and post-2-MEV, we are not sure why the change in Care with Resources occurred.

Table 2. Environmental attitudes and values of control students $(N=37)$

\begin{tabular}{|c|c|c|c|c|c|c|c|}
\hline & \multicolumn{2}{|c|}{ Mean Scores } & \multicolumn{2}{|c|}{ Std. Deviation } & \multirow[b]{2}{*}{$\boldsymbol{T}$} & \multirow[b]{2}{*}{$\boldsymbol{P}$} & \multirow{2}{*}{$\begin{array}{l}\text { Effect } \\
\text { size }\end{array}$} \\
\hline & Pre & Post & Pre & Post & & & \\
\hline Preservation & 4.27 & 4.37 & 0.70 & 0.67 & -1.81 & 0.080 & 0.14 \\
\hline Intent of Support & 3.95 & 3.91 & 0.97 & 0.93 & 0.37 & 0.713 & 0.04 \\
\hline Care with Resources & 4.31 & 4.55 & 0.94 & 0.65 & -2.35 & $0.025 *$ & 0.29 \\
\hline Enjoyment of Nature & 4.59 & 4.64 & 0.66 & 0.65 & -0.78 & 0.438 & 0.06 \\
\hline Utilization & 2.37 & 2.32 & 0.76 & 0.80 & 0.75 & 0.460 & 0.06 \\
\hline Altering Nature & 2.88 & 2.72 & 0.91 & 0.98 & 1.63 & 0.113 & 0.17 \\
\hline Human Dominance & 1.68 & 1.78 & 0.74 & 0.75 & -0.95 & 0.348 & 0.13 \\
\hline
\end{tabular}

Note: * statistically significant, $p<0.05$

For both Earthkeepers participants and the control group, values and attitudes were fairly pro-environmental even in the pre-test. In the Earthkeepers group, there were more and stronger changes to even more pro-environmental values and attitudes than were apparent for the control group (see Table 3). 
Table 3. Environmental attitudes and values in experimental $(\mathrm{N}=106)$ and control groups $(\mathrm{N}=37)$

\begin{tabular}{|c|c|c|c|c|c|c|c|c|}
\hline & \multicolumn{5}{|c|}{ Mean Scores } & \multicolumn{3}{|c|}{ Standard Deviation } \\
\hline & \multicolumn{2}{|c|}{ PRE } & \multicolumn{2}{|c|}{ POST } & \multicolumn{2}{|c|}{ PRE } & \multicolumn{2}{|c|}{ POST } \\
\hline & Exp & Con & Exp & Con & Exp & Con & Exp & Con \\
\hline Preservation & 4.06 & 4.27 & 4.28 & 4.37 & 0.73 & 0.70 & 0.78 & 0.67 \\
\hline Intent of Support & 3.60 & 3.95 & 3.90 & 3.91 & 1.00 & 0.97 & 0.96 & 0.93 \\
\hline $\begin{array}{l}\text { Care with } \\
\text { Resources }\end{array}$ & 4.14 & 4.31 & 4.47 & 4.55 & 0.93 & 0.94 & 0.86 & 0.65 \\
\hline $\begin{array}{l}\text { Enjoyment of } \\
\text { Nature }\end{array}$ & 4.40 & 4.59 & 4.45 & 4.64 & 0.78 & 0.66 & 0.86 & 0.65 \\
\hline Utilization & 2.41 & 2.37 & 2.26 & 2.32 & 0.77 & 0.76 & 0.86 & 0.80 \\
\hline Altering Nature & 2.81 & 2.88 & 2.60 & 2.72 & 0.92 & 0.91 & 0.98 & 0.98 \\
\hline Human Dominance & 1.87 & 1.68 & 1.81 & 1.78 & 0.81 & 0.74 & 0.88 & 0.75 \\
\hline
\end{tabular}

The position with the most pro-environmental mean on the pre-test, Enjoyment of Nature, is the one that changed the least, which is not surprising. Both the fairly high pretest means and the greater changes in Preservation than in Utilisation is consistent with findings in other studies that have used the 2-MEV.

The control group started out with higher preservation scores than the experimental group. Even if we cannot be sure about the reason, we might suppose that the results were affected by a small number of respondents in the control group who consisted of two school classes only. Because of this, the group could have been affected by more active teachers or more environmentally oriented curricula than it was the case of the experimental groups before they participated in the Earthkeepers programme. Concerning different size of the groups, no statistical comparison of their attitudes was calculated.

The impact of the programme on pupils' ecological knowledge was analyzed with the ECQ instrument. In the test, pupils gained 0 or 1 point for every wrong or correct question. Table 4 provides information about ecological knowledge for the experimental group. For the analysis, the Wilcoxon pair test was used. 
Table 4. Students' ecological understanding before and after the programme $(N=106)$

\begin{tabular}{|c|c|c|c|c|c|c|c|c|}
\hline \multirow[b]{2}{*}{ Concepts } & \multicolumn{2}{|c|}{$\begin{array}{l}\text { ECQ mean } \\
\text { score } \\
\text { (\% correct) }\end{array}$} & \multicolumn{2}{|c|}{$\begin{array}{l}\text { Std. } \\
\text { Deviation }\end{array}$} & \multirow[b]{2}{*}{ Gain } & \multirow[b]{2}{*}{$z$} & \multirow[b]{2}{*}{$\boldsymbol{P}$} & \multirow{2}{*}{$\begin{array}{l}\text { Effec } \\
\text { size }\end{array}$} \\
\hline & Pre & Post & Pre & Post & & & & \\
\hline Energy Flow & 36 & 55 & 1.18 & 1.09 & 19 & 6.58 & $<0.0001$ & 1.1 \\
\hline Cycling & 58 & 78 & 0.84 & 0.84 & 20 & 4.33 & $<0.0001$ & 0.71 \\
\hline Interrelationships & 44 & 71 & 0.68 & 0.69 & 27 & 4.35 & $<0.0001$ & 0.65 \\
\hline Change & 54 & 74 & 0.73 & 0.65 & 20 & 3.91 & $<0.0001$ & 0.6 \\
\hline Total Score & 45 & 65 & 2.01 & 2.07 & 20 & 7.52 & $<0.0001$ & 1.28 \\
\hline
\end{tabular}

In the control group, no significant change between pre- and post-tests was found for Energy Flow $(\mathrm{N}=20, \mathrm{z}=1.26, \mathrm{p}=0.2)$, Interrelationships $(\mathrm{N}=17, \mathrm{z}=0.21, \mathrm{p}=0.83)$, or Change $(\mathrm{N}=17, \mathrm{z}=0.94, \mathrm{p}=0.34)$. The exception was in the understanding of Cycles where the control group scored significantly higher in the post-test $(N=22, z=2.12, p=0.03)$. Because the control group did not participate in any environmental education programme between pre- and post-test, we cannot explain this difference.

As we can see, in all of the measured concepts pupils from the experimental group significantly increased their level of understanding. The effect can be interpreted as strong.

In the control group, ecological knowledge changed in terms of understanding material cycles and was not statistically significant for the other concepts.

Of the 120 pupils who participated in the program, 107 filled in the PFTS survey after finishing the school part of the programme. Of that number, 72 respondents (60 \% of the participants) declared they received their key " $Y$ " for altering their environmental behaviour, e.g. reduction of energy consumption or more responsible management of material sources. Moreover, 66 respondents ( $55 \%$ of the participants) obtained the key for sharing some of the programme activities with other children.

\section{Discussion}

There are several methodological limits in this study. The evaluation focuses on piloting the programme in the centre. We can presume that the lack of experience of the centre's staff could have negatively influenced the effectiveness of the programme. As a result, the evaluation on the programme conducted by an inexperienced staff should not be generalized.

Moreover, the number of respondents (especially for the control group) is limited. We assume that more groups participating in the programme will provide better insight into the way the programme works. 
In spite of its methodological limits, the results follow similar patterns as other evaluation studies of the programme (Johnson \& Manoli, 2008a,b, Johnson, 2005, Manoli \& Johnson, 2008, Martin, 2003). Pupils and teachers were highly satisfied with the programme, and it is reasonable to suppose that the programme had a positive impact on pupils' ecological knowledge and attitudes.

Many authors support the assumption that pupils of the age of the Earthkeepers participants usually have positive attitudes towards nature and the environment (Kaplan \& Kaplan, 2002, Krajhanzl, 2012). It might explain a relatively high level of initial proenvironmental attitudes found in this study.

The analysis of the implementation process suggested a possible barrier to further dissemination of the programme among environmental education centres in the Czech Republic or other countries in the region. The difficulties of the implementation process calls for very strong motivation within an environmental education centre. We assume that for the centre used in this study, a combination of more motivational factors were in play. There was some familiarity with the earth education approach in the country already, even if it involved some misconceptions. The earth education workshop in the Centre helped to clarify the philosophy of the earth education approach and aligned with the way the staff thought about environmental education. Financial support provided resources for the technical and organizational needs of the programme. Altogether, awareness, enthusiasm, and an adequate budget led the Centre to commit to overcoming the barriers and to implement the programme.

Although the translation process is probably the most difficult part of implementation, it must be said that after finishing the national version of the programme, all the translated materials can be shared with other centres in the same country. It means that when the first centre overcomes this barrier, implementation for other centres from the same country becomes substantially less demanding.

The long-term success of the programme might be influenced by the willingness of schools (pupils' parents) to pay for participation. Although there is a long tradition of environmental education in the Czech Republic and it is common that schools participate in residential programmes, in times of economic turmoil such willingness might be undermined. We can also suppose that because of limited resources schools might prefer cheaper programmes, even with questionable or unproven effectiveness.

To avoid that and to help future dissemination of the programme, two different steps might be useful. First, the centre can utilize the high level of satisfaction of the participating schools throughout the pilot of the programme and incorporate the programme into their regular curricula. Second, to increase the awareness about the programme, it might be helpful to disseminate the programme to other centres in different regions of the Czech Republic.

However, the long-term sustainability of a programme that is effective but also demanding and relatively expensive calls for educational environment that favours effectiveness over simple low-cost solutions. 


\section{Conlusion}

The evaluation demonstrated the impact of the Earthkeepers programme on the environmental attitudes and ecological knowledge of Czech pupils. Morover, the programme was succesful in terms of the satisfaction of both teachers and pupils.

From the point of view of the ecological centre staff, the implemenation process was rewarding, but also demanding. It might be supposed that the relative difficulties of the translation process might be a barrier to further dissemination of the programme to other countries.

Regardless of the presented findings, further evaluation of the program would shed more light into the way the programme works. Because of the limited number of respondents, we recommend continuing with the evaluation of the programme in future and verifying the results on a higher sample.

\section{Acknowledgement}

The programme Earthkeepers is conducted in the Czech Republic as part of the project Environmental education in the Bohemian Paradise (CZ.1.07./1.1.00/14.0128), managed by the Bohemian Paradise Ecological Education Centre. The project is co-financed by the European social fund and the national budget of the Czech Republic.

\section{References:}

- Bogner, F. X., \& Wiseman, M. (2006). Adolescents' attitudes towards nature and environment: Quantifying the 2-MEV model. Environmentalist, 26(4), 247-254. Retrieved from http://link.springer.com/10.1007/s10669-006-8660-9 http://dx.doi.org/10.1007/s10669-006-8660-9

- $\quad$ Cincera, J. (2007). Environmentalni vychova. Od cilu k prostredkum. Brno: Paido.

- Cincera, J. (2007). Steve van Matre v Cesku. Envigogika, 2(3), Retrieved from http://www.envigogika.cuni.cz/index.php/Envigogika/article/view/119/html 119 http://dx.doi.org/10.14712/18023061.119

- Felix, L., \& Johnson, B. (2013). Back in the classroom: Teacher follow-through after an earth education program. Applied Environmental Education and Communication, 12(3),

- Hakr, T., \& Cincera, J. (2006). Earth education - vychova o Zemi. [Final essay]. Liberec: Technická univerzita Liberec. Retrieved from http://www.envigogika.cuni.cz/index.php/Envigogika/article/view/85/pdf_85_zdroj

- Johnson, B., \& Manoli, C. C. (2008). Using Bogner and Wiseman's Model of Ecological Values to measure the impact of an earth education programme on children's environmental perceptions. Environmental Education Research, 14(2), 115-127. Retrieved from http://www.tandfonline.com/doi/abs/10.1080/13504620801951673 http://dx.doi.org/10.1080/13504620801951673

- Johnson, B., \& Manoli, C. C. (2008). Using the Model of Ecological Values to Examine Stability of and Changes in Children's Environmental Perceptions Over 
Time. Paper presented at the Annual Meeting of the National Association of Research in Science Teaching. Baltimore.

- Johnson, B. (2005). Earth Education Research. A paper presented at the Environmental Education Research Symposium. Albuquerque, New Mexico: Amer Center for the Study of.

- Johnson, B., \& Manoli, C. C. (2011). The 2-MEV Scale in the US: A measure of children's environmental attitudes based on the Theory of Ecological Attitude. Journal of Environmental Education, 42(2), 84-97. Retrieved from http://www.tandfonline.com/doi/abs/10.1080/00958964.2010.503716 http://dx.doi.org/10.1080/00958964.2010.503716

- Kaplan, R., \& Kaplan, S. (2002) Adolescents and the Natural Environment: A Time Out?. In Kahn, P.H., Kellert, S. R. (Ed.), Children and Nature: Psychological, sociocultural, and evalutionary investigations. Cambridge: Massachussetts Institute of Technology.

- Krajhanzl, J. (2012) Špetka ekopsychologie pro ekopedagogickou praxi. In A. Máchal, H. Nováčková, \& L. Sobotková (Eds.), Úvod do environmentální výchovy a globálního rozvojového vzdělávání. Soubor učebních textü. (pp. 95-110). Brno: Lipka.

- Ledvinova, J. et al. (1992). Vychova pro budoucnost (cesty ekologicke vychovy). Praha: MZP, Sdruzeni Tereza.

- Manoli, C., \& Johnosn, B. (2008). Factors Influencing Students' Ecological Actions Following Participation in an Earth Education Program. Paper presented at the Annual Meeting of the National Assocation of Research in Science Teaching. Baltimore.

- Manoli, C. C., Johnson, B., Hadjichambis, A. C., Paraskeva-Hadjichambi, D., Georgiou, Y., \& Ioannou, H. . Evaluating the impact of the Earthkeepers earth education program on children's ecological understandings, values and attitudes, and behaviour in Cyprus. Studies in Educational Evaluation. (in press). .

- Manoli, C., Johnson, B., \& Dunlap, R. (2007). Assessing children's views of the environment: Modifying the New Ecological Paradigm Scale for use with children. Journal of Environmental Education, 38(4), 3-13. Retrieved from http://www.tandfonline.com/doi/abs/10.3200/JOEE.38.4.3-13 http://dx.doi.org/10.3200/JOEE.38.4.3-13

- Martin, D. (2003). Research in Earth Education. Zeitschrift für Erlebnispädagogik. Research in Earth Education. Zeitschrift für Erlebnispädagogik, 23(5), 32-47.

- Matre, S. van, Johnosn, B., (1998). Earthkeepers. Greenville: The Institut for Earth Education. .

- Wohlers, L., \& Johnson, B. (2003). A programmatic approach: Purposeful experiences. Zeitschrift Für Erlebnispädagogik. , 23(5/6), 14-22. 


\section{Appendix 1 The Environmental Scale (2-MEV) PRESERVATION}

Intent of support

1. If I ever have extra money, I will give some to help protect nature.

6. I would help raise money to protect nature.

11. I try to tell others that nature is important.

Care with resources

2. To save energy in the winter, I make sure the heat in my room is not on too high.

7. I always turn off the light when I do not need it any more.

12. I try to save water by taking shorter showers or by turning off the water when I brush my teeth.

Enjoyment of nature

3. I would like to sit by a pond and watch dragonflies.

8. I like to go on trips to places like forests away from cities.

13. I like the quiet of nature.

\section{UTILIZATION}

Altering nature

4. People have the right to change the environment (nature).

9. I like a grass lawn more than a place where flowers grow on their own.

14. To feed people, nature must be cleared to grow food.

16. Weeds should be killed because they take up space from plants we need.

\section{Dominance}

5. Building new roads is so important that trees should be cut down.

10. Because mosquitoes live in swamps, we should drain the swamps and use the land for farming.

15. People are supposed to rule over the rest of nature.

Note: In the Revised 2-MEV completed by participants, items are mixed and not listed by factor. 


\section{Jan Činčera}

Masaryk University Brno, Department of Environmental Studies \& Technical University of Liberec, Department of Pedagogy and Psychology

The author focuses on theory of environmental education and education for sustainable development. He cooperates with environmental centres as a programme consultant and evaluator.

\section{Bruce Johnson}

University of Arizona, Department of Teaching, Learning and Sociocultural Studies

Bruce Johnson is Professor of environmental learning and science education at the University of Arizona, where is also serves as Director of the Earth Education Research and Evaluation Team and Co-Director of the STEM Learning Center. He is also the International Program Coordinator of The Institute for Earth Education, an international non-profit educational organization. 